\title{
Characterization of banana bunchy top virus on Sumatra (Indonesia) wild banana
}

\author{
RUTH FETI RAHAYUNIATI ${ }^{1,2, \vartheta}$, SEDYO HARTONO ${ }^{2, v \downarrow}$, SUSAMTO SOMOWIYARJO ${ }^{2}$, \\ SITI SUBANDIYAH ${ }^{2,3}$, JOHN E. THOMAS ${ }^{4}$ \\ ${ }^{1}$ Department of Agrotechnology, Faculty of Agriculture, Universitas Jenderal Soedirman. Jl. Dr. SuparnoNo. 61, Purwokerto Utara, Banyumas 53123, \\ Central Java, Indonesia. Tel./fax.: +62-281-638791, `email: ruth.rahayuniati@unsoed.ac.id \\ ${ }^{2}$ Doctoral Program in Agricultural Science, Faculty of Agriculture, Universitas Gadjah Mada. J1 Flora, Bulaksumur, Sleman 55281, Yogyakarta, \\ Indonesia. Tel.: +62-274-563062,vemail: sedyo_h@yahoo.com \\ ${ }^{3}$ Research Center for Biotechnology, Universitas Gadjah Mada. Jl. Teknika Utara, Sleman 55281, Yogyakarta, Indonesia \\ ${ }^{4}$ The Queensland Alliance for Agriculture and Food Innovation, University of Queensland. Building 80, 306/306 Carmody Rd, St Lucia, QLD 4072, \\ Australia
}

Manuscript received: 14 November 2020. Revision accepted: 11 February 2021.

\begin{abstract}
Rahayuniati RF, Hartono S, Somowiyarjo S, Subandiyah S, Thomas JE. 2021. Characterization of banana bunchy top virus on Sumatra (Indonesia) wild banana. Biodiversitas 22: 1243-1249. Banana bunchy top virus (BBTV) has been a major constrain on banana production worldwide. This virus infection is mostly found in banana cultivation. The study aimed to characterize the BBTV on Sumatra wild bananas. The survey to collect seeds and typical symptomatic samples had been done in 2017 and 2019 in West Sumatra, South Sumatra, and Bengkulu. The transmission test of the virus was conducted by using the viruliferous vector on four wild banana species, while the identity of BBTV confirmed by nucleotide sequences analysis using primer pairs of DNA R and DNA S. Musa acuminata subsp. sumatrana (AA) have been found naturally infected by BBTV. The transmission confirmed on M. acuminata subsp. longipetiolata, M. acuminata subsp. malacensis, M. acuminata subsp. halabanensis and Musa sp. with typical bunchy top symptoms. The incidence on test plants were 40\%, 80\% 20\%, 20\% and 20\%, respectively. The virus infection on Sumatra wild bananas prolonged the incubation periods in comparison to cv Mas. BBTV of M. acuminata subsp. sumatrana is similar to the BBTV MK940788 and MN073184 from Sumatra. This is the first report of BBTV on Sumatra wild banana. The result can be used as a reference to study the resistance of the banana against BBTV.
\end{abstract}

Keywords: Banana bunchy top virus, BBTV, wild banana, characterization

\section{INTRODUCTION}

Banana and plantain are valuable food crops in the world, staple food in some or cash crop for local market and export, particularly in the developing countries. Banana is considered the fourth important global food, after rice, wheat, and milk (Tchatchambe et al. 2020). Indonesian export of banana decreased by about $22.35 \%$ from 2018-2019. However, the average banana production increased by around $0.22 \%$ (BPS 2019).

Banana Bunchy Top Disease (BBTD) is one of the major diseases in banana, caused by Banana bunchy top virus (BBTV). The virus is transmitted by aphid Pentalonia nigronervosa Coquerel, in a persistent non-circulative manner. The disease might spread a long distance by its sucker, corms, and plantlet of tissue culture during the trade among islands or countries (Wickramaarachchi et al. 2016). Banana bunchy top virus infects most banana cultivars with stunting and chlorosis/necrosis symptoms, resulting in major economic losses of the crop. This virus is regarded as the most economically destructive of plant virus disease and contributed up to $100 \%$ decreased yield of banana and plantain (Qazi 2016).

Banana bunchy top virus consists of six components of ssDNA each size ranging from 1018 to $1111 \mathrm{bp}$. They are
DNA-R, DNA-S, DNA-M, DNA-N, DNA-C, and DNA-U3 (Stainton et al. 2015; Wickramaarachchi et al. 2016; Kumar et al. 2017; Kakathi and Nath 2018). Each DNA (Deoxyribonucleic acid) has a specific function. DNA-R encodes a master replication-associated protein (M-Rep), DNA-S encodes the coat protein (CP) (Stainton et al. 2015; Wickramaarachchi et al. 2016; Arumugam et al. 2017). DNA-N encodes nuclear shuttle protein (NSP) (Baldodiya et al. 2019; Ji et al. 2019) and DNA-M acts as movement protein (Debbarma et al. 2019). Generally, BBTV is divided into two groups; the Asian or South East Asia and the Pacific or Pacific Indian Ocean Groups (Stainton et al. 2015; Wickramaarachchi et al. 2016; Das and Banerjee 2018). Detection of Indonesian BBTV was done and reported for the isolates from Java (Lestari and Hidayat 2018) and Bali (Wirya et al. 2020). A previous study analyzed the genetic of the Sumatra population and reported low diversity compared to those from Java and Bali. The BBTV isolates in Sumatra did not show any recombination however, the infection was higher in bananas with $\mathrm{AAB}$ or $\mathrm{ABB}$ than those in bananas with $\mathrm{AA}$ or AAA genomes (Chiaki et al. 2015).

Wild banana (AA) is a progenitor of the cultivated one and Sumatra island is one of the origins of wild bananas, hence, vital for conservation and preservation as the 
genetic resources of cultivated bananas. Information about the resistance of wild bananas to BBTV is scarce. This study is the first report of bunchy top disease on the Sumatra wild banana and it focuses on characterizing the BBTV and confirmed the susceptibility of the host through transmission test.

\section{MATERIALS AND METHODS}

\section{Survey and sampling}

The survey of BBTV was carried out in Sumatra Island, Indonesia (Figure 1) during the years 2017 and 2019. Sumatra is a renowned origin of wild banana and available abundantly on the island. Purposive random sampling was adopted and conducted across West Sumatra, South Sumatra, and Bengkulu provinces, randomly collecting young banana leaves with the symptom of bunchy top directly from the field (Figure 2). Additionally, the infected, cultivated banana around the wild ones was subjected to observation and sampled across the sampling locations. All the collected leaf samples were preserved in the silica blue gel.

\section{Banana bunchy top virus detection and molecular characterization}

The collected leaf samples were subjected to DNA extraction, conducted at the Laboratory of Plant Protection at Universitas Gadjah Mada, Yogyakarta, Indonesia. Ten grams of dried leaf sample of each material was extracted using ISOLATE II Genomic DNA Kit (Bioline Reagents Limited, London, UK). Extraction method was following the instruction provided by the kit. The virus was detected by the Polymerase Chain Reaction (PCR) using two sets of specific primers (Table 1), according to Stainton et al. (2015).

The DNA was amplified using PCR Kit of MyTaq TM HS Red Mix (Bioline). A total of $12.5 \mu$ reaction consisted of $1 \mu \mathrm{L}$ of DNA template, $1 \mu \mathrm{L}$ of primer sets, $5 \mu \mathrm{L}$ of My Taq Red Mix, and $5.5 \mu \mathrm{L}$ of RNAse free water. Initial denaturation was performed at $94^{\circ} \mathrm{C}$ for $1 \mathrm{~min}$, continued with 35 cycles of denaturation at $94^{\circ} \mathrm{C}$ for $20 \mathrm{~s}$, annealing at $60^{\circ} \mathrm{C}$ for $30 \mathrm{~s}$, extension at $72^{\circ} \mathrm{C}$ for $1 \mathrm{~min}$, and ended with the final extension at $72^{\circ} \mathrm{C}$ for $3 \mathrm{~min}$. The electrophoresis was carried out using $1 \%$ agarose gel in $1 \times$ TBE buffer and visualized by staining using ethidium bromide $(\mathrm{EtBr})$. Then the PCR products were sent to First BASE Laboratory, Malaysia for DNA sequencing.

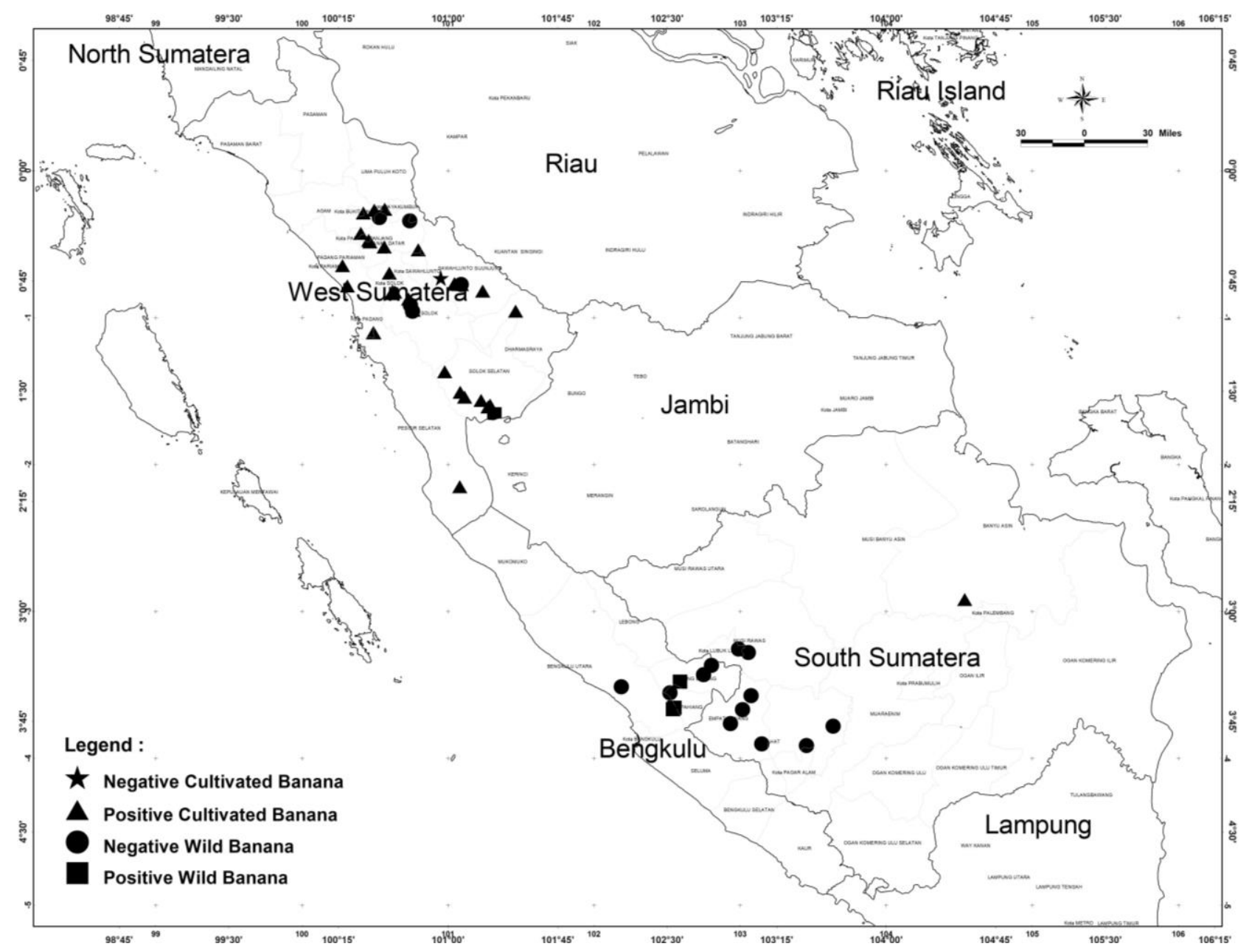

Figure 1. Sampling location of wild banana in West Sumatra, Bengkulu, and South Sumatra provinces, Indonesia 


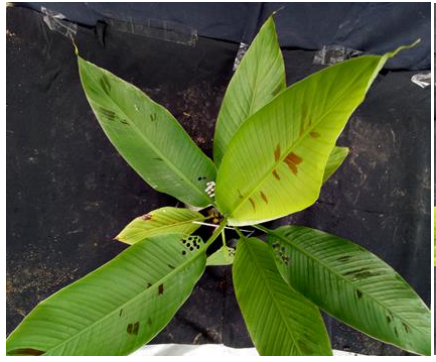

A

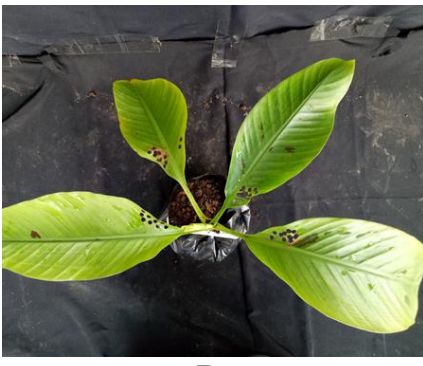

B

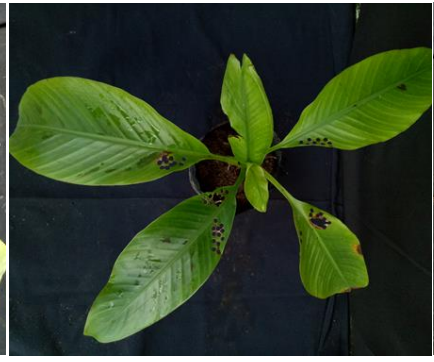

C

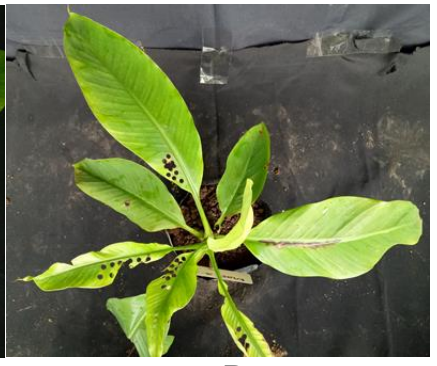

D

Figure 2. Disease symptom and severity on wild banana after inoculation. A: No symptom, B: Mild symptom, C: Intermediate symptom, D. Severe symptom

Table 1. Specific primer DNA R and DNA S BBTV

\begin{tabular}{llc}
\hline DNA target & Primer sequence & Amplicon size \\
\hline DNA R & Forward: 5'-TTGAGAAACGAAAGGGRAGC-3' & $1111 \mathrm{bp}$ \\
& Reverse: 5'-GGTGTGCGCCTGGGAAG-3' & 1075 bp \\
DNA S & Forward: 5'-GGTTCCTGAAAAYACCGTC-3' & \\
& Reverse: 5'-AATATTGAYCCTARMGACGAG-YAGTC-3' \\
\hline
\end{tabular}

\section{Sequence and phylogenetic analysis}

Sequence contigs were assembled and aligned using Algorithm Clustal W of MEGA X program (Kumar et al. 2018). Grouping for BBTV was based on the DNA-R sequence analysis. The phylogenetic tree was constructed following the maximum likelihood method. The bootstraps of 1.000 replicates were used to verify the significance of the tree. Banana bunchy top virus sequence from GenBank MN073184, MK940788, AB847628, AF416468, AF416479, KM607663, KM607658, and KP876498 were used in DNA-R analysis. The DNA of Abaca bunchy top virus (ABTV) sequence EF546807 was used as the outer group.

\section{Transmission test}

Four species of wild banana, $M$ acuminata subsp. malacensis, $M$ acuminata subsp. longipetiolata, $M$ acuminata subsp. halabanensis, and Musa sp. were grown by seeds on the sterilized soil medium, consisted of compost and soil (1:1), and maintained in the screen house. A total of ten plants per species were under assessment. The transmission test conducted using the young plants a month after seedling. The BBTV inoculum was the isolate obtained from banana cultivar Mas and kept cultivated continuously in the greenhouse. $P$. nigronervosa mass rearing colony was used as the vector. The BBTV- infected banana cultivars Mas was used as the positive control.

According to Suparman et al. (2017) and Jebakumar et al. (2018), the transmission technique was done with a slight modification in the material usage, size, the old of the aphids, and the number of the aphids. Non-viruliferous (instar 3) aphids transferred from a healthy plant to the inoculum sources plant. After 48 hours of the acquisition period, the aphids were transferred individually using a wet paintbrush to the tested healthy seedlings. Each plant was infested with 20 viruliferous aphids, placed on the cigar leaf base. The inoculated plants were placed in a screen box and incubated in a room with a temperature range of $25-30^{\circ} \mathrm{C}$ for five days. On the last day of the incubation period, all the aphids were sprayed using insecticide with a 500 ppm lambda cyhalothrin active ingredient.

Leaf samples were collected from the infected single plant after 21-weeks post inoculation (WPI). Total DNA was isolated from the samples following the instruction on the ISOLATE II Genomic DNA Kit (Bioline Reagents Limited, London, UK). A back-to-back primer DNA-R of BBTV applied for polymerization reaction producing 1100 bp (Stainton et al. 2015). PCR products were run on $1 \%$ agarose gel, stained with ethidium bromide, and visualized under UV transilluminator.

\section{Disease incidence}

Disease incidence was assessed at the last observation and recorded based on the host's visual symptoms. The disease symptoms were inspected in all the plants, a single plant with bunchy top symptom was considered as infected (Ngatat et al. 2017). Disease incidence was calculated by the percentage of the infected plant over the total number of assessment plants.

$$
\text { Disease Incidence }=\frac{\Sigma \text { symtomatic plant }}{\text { Total plant sample }} \times 100 \%
$$

Disease severity was observed weekly. A four-score infection was modified based on the visual symptom (Leiwakabessy et al. 2017; Wirya et al. 2020) (Table 2). The severity was calculated using a disease severity formula.

Disease Severity $=\frac{\sum \mathrm{i}(\mathrm{ni} \times \mathrm{vi})}{N \times Z} \times 100 \%$

Where;

ni: infected sample

vi: score at the time of observation

$\mathrm{N}$ : total plants

$\mathrm{Z}$ : highest score 
Table 2. Level infection according to Leiwakabessy et al. (2017)

\section{Score Description of symptom}

$0 \quad$ No symptom

1 Mild symptom. Limited vein clearing and dark green streaks on the lower part of lamina and petiole. No significant reduction of lamina width

2 Intermediate symptom. Vein clearing, upturned leaf, chlorotic, and ragged margins. Significant reduction in petiole length, distance, and lamina width

3 Severe symptom. Brittle lamina with upturned, chlorotic, and ragged margins, sometimes with necrotic symptoms. Leaves failed to emerge, giving a clear bunched appearance

Area Under Disease Progress (AUDPC)

AUDPC is measured based on the comparison between disease severity and time (Ngatat et al. 2017). It is calculated by the formula:

$$
\operatorname{AUDPC}=\Sigma\left(\left(\mathrm{y}_{\mathrm{i}}+\mathrm{y}_{\mathrm{i}+1}\right) / 2\right) \times\left(\mathrm{t}_{\mathrm{i}+1}-\mathrm{t}_{\mathrm{i}}\right)
$$

Where; 'yi' the proportion of the infected plant at the ' $\mathrm{i}$ ' th observation, 'ti' is time in days at the ' $\mathrm{i}$ ' th observation.

\section{RESULTS AND DISCUSSION}

\section{Banana bunchy top virus characterization on wild banana}

The wild bananas collected from West Sumatra, Bengkulu, and South Sumatra provinces were Musa acuminata subsp. sumatrana, M. acuminata subsp. halabanensis, M. acuminata subsp. longipetiolata and $M$. acuminata subsp. malacensis. Two $M$ acuminata subsp. sumatrana from West Sumatra and Bengkulu showed the specific symptoms of bunchy top disease. The initial signs were narrow leaves on the top of the plant, chlorosis on the leaves edge, and a dark green streak on the midrib and leaf stem (Figure 3). These symptoms had been reported as typical of banana bunchy top disease in Sumatra (Chiaki et al. 2015). It did not find any wild banana with typical bunchy top symptoms in South Sumatra during the survey.

Leaf samples were detected using the PCR method to ensure virus infection (Figure 4). DNA-R of BBTV on infected wild subsp. sumatrana from Bengkulu (W1) and West Sumatra (W2) was amplified at 1104 bp and the DNA $\mathrm{S}$ of W1 and W2 were amplified at $1058 \mathrm{bp}$. The infected cultivar Ambon Kuning cultivars from Bengkulu (C1) and West Sumatra (C2) was used as positive control and the healthy plant as negative control $(\mathrm{N})$.

The length of DNA-R is $1104 \mathrm{bp}$ and the ORF of DNA$\mathrm{R}$ at the nucleotide number 103-963, encodes 287 amino acids responsible for viral putative replication initiation protein (Rep). DNA-S has a length of 1058bp and showed an ORF at nucleotide number 212-724 and encodes 170 amino acids that coding a coat protein (CP). The sumatrana isolates have two common CR-SL (TATTATTAC) regions at nucleotide number 13-21 and CR-M (GC rich region) in the intergenic region.

\section{Sequence and phylogenetic analysis}

According to Das and Banerjee (2018), it can be stated that BBTV of $M$ acuminata subsp. sumatrana from West Sumatra (GM 103047) and Bengkulu (GM 109003) is a member of the Asian/South East Asia Group. The tree shows the GM103047 share cluster with Ambon Kuning/Gros Mitchel (MN073184) from the same province. Additionally, the same BBTV is observed in two bananas from Bengkulu province, they are GM 109003 and MK 940788 (Figure 5). This phenomenon explained no differences between the isolates of wild bananas with the cultivated ones from the same area. Both $M$ acuminata subsp. sumatrana were group into two clusters based on the origins.

\section{Transmission test}

Virus infection on the transmission test was confirmed by a PCR using the BBTV isolate of Mas cultivar. The plant was observed after the vector was killed by insecticide. The disease incidence data are presented in Table 3, and the progression of the disease severity in Figure 6. At week 3, four plants of the subspecies longipetiolata showed the first symptom. The lamina margin showed chlorosis symptoms, meanwhile, dark green streak and dot emerged in the lower lamina and petiole. The new leaf decreased in size, length, and width, but the vein was clearing. The DNA R of the virus was amplified at 1104 bp. Disease severity of longipetiolata increased from $13.3 \%$ on 2-3 WPI to $40 \%$ on 14-15 WPI, and the curve stabilized at $40 \%$ until 21 WPI. On week 4, cultivar Mas showed the initial symptoms of bunchy top disease. Also, mild symptoms were observed in both banana plants. Mas Cultivar showed 100\% disease incidence with $93 \%$ disease severity at 20 to 21 WPI. However, the subspecies malacensis had a delayed first symptom for 10 weeks, followed by mild symptoms at 11 WPI with $6.67 \%$ severity. The severity increased up to $60 \%$ and stabilized on the 20 WPI; however, the disease incidence was up to $80 \%$.

Musa sp. showed the first symptom on week 14 . The disease severity increased from $6.67 \%$ on week 14 to $20 \%$ on week 18 . The severity did not increase until week 21 when the disease incidence reached 20\%. Subspecies halabanensis expressed the disease symptom in week 20 with disease severity $6.67 \%$ and incidence of the disease 
about $20 \%$ in week 21. Furthermore, Figure 6 illustrates a slower response of Sumatra wild banana to the BBTV infection than that of Mas cultivar. They might have a distinct resistance response to the bunchy top virus. The response test to wild banana showed that subsp. malacensis is the most susceptible to BBTV. A considerably slow response to the virus infection was expressed by the subsp. halabanensis. Therefore, the subsp. halabanensis is evidently more resistant than the other wild bananas tested up to 21 weeks after inoculation. Among the wild bananas, the AUDPC indicated significant differences. Lowest AUDPC (3.33) was recorded on subsp. halabanensis and the highest was observed on subsp. longipetiolata (566.67).
Table 3. The Disease Incidence at 21-week post transmission

\begin{tabular}{|c|c|c|c|}
\hline Banana sample & $\begin{array}{c}\text { Disease } \\
\text { incidence } \\
(\%)\end{array}$ & $\begin{array}{c}\text { Disease } \\
\text { severity } \\
(\%)\end{array}$ & AUDPC \\
\hline M. acuminata cv Mas & 100.00 & 100.00 & 1732.22 \\
\hline M. acuminata subsp. longipetiolata & 40.00 & 40.00 & 566.67 \\
\hline M. acuminata subsp. malacensis & 60.00 & 60.00 & 416.67 \\
\hline Musa sp & 20.00 & 20.00 & 110.00 \\
\hline M. acuminata subsp. halabanensis & 20.00 & 6.67 & 3.33 \\
\hline
\end{tabular}

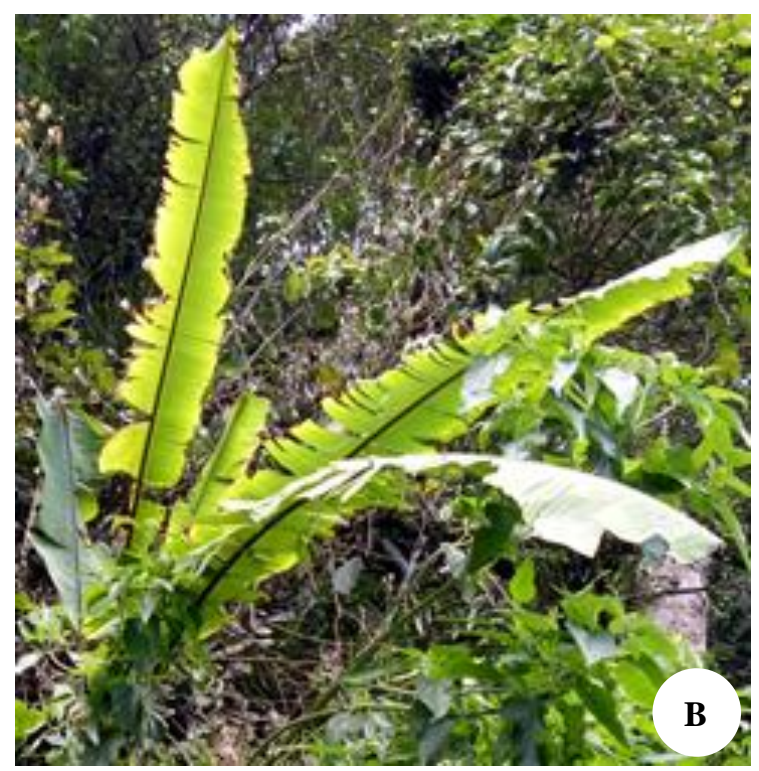

Figure 3. Banana bunchy top virus symptom on wild banana. A. Bunchy top disease symptom on Musa acuminata subsp. sumatrana in Bengkulu, B. Bunchy top disease symptom on Musa acuminata subsp. sumatrana in West Sumatra
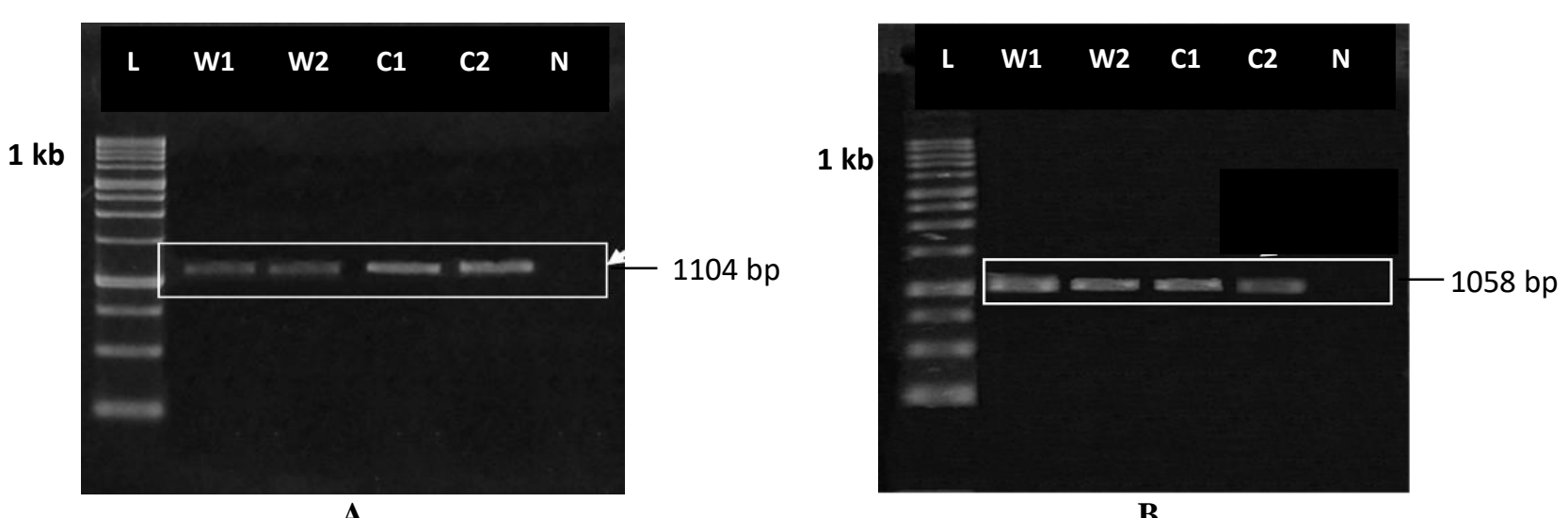

Figure 4. Visualization of DNA amplification of BBTV from wild banana and cultivated banana on $1 \%$ agarose gel. A. Amplification DNA-R of BBTV. B. Amplification DNA-S of BBTV. L= Ladder $(1 \mathrm{~Kb}), \mathrm{W} 1=M$ acuminata subsp. sumatrana (Bengkulu), W2=M acuminata subsp. sumatrana (West Sumatra), C1= Banana cv. Ambon Kuning (Bengkulu), C2= Banana cv. Ambon Kuning (West Sumatra), N= Negative control (cv. Mas) 


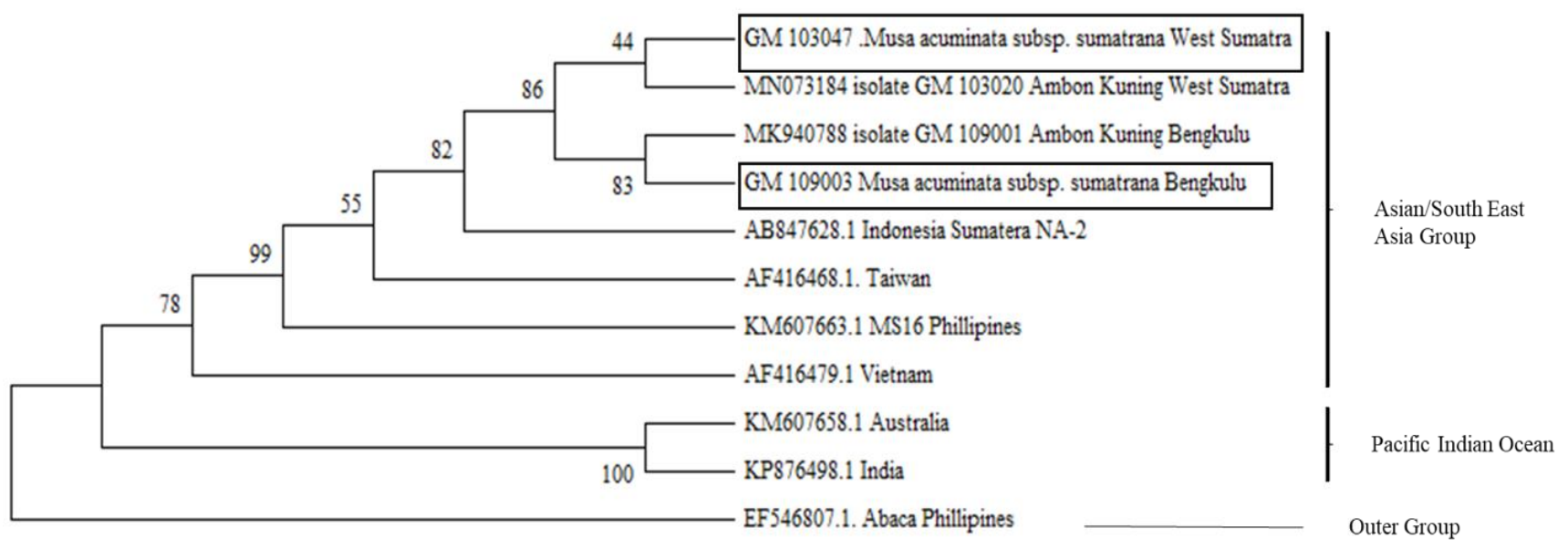

Figure 5. Phylogenetic tree showing the BBTV closely relationship of Sumatra wild banana to cultivated banana based on the DNA-R. Abaca Bunchy Top Virus on Abaca was included as an outgroup. The tree was inferred by using the maximum likelihood method with 1000-bootstrap replication

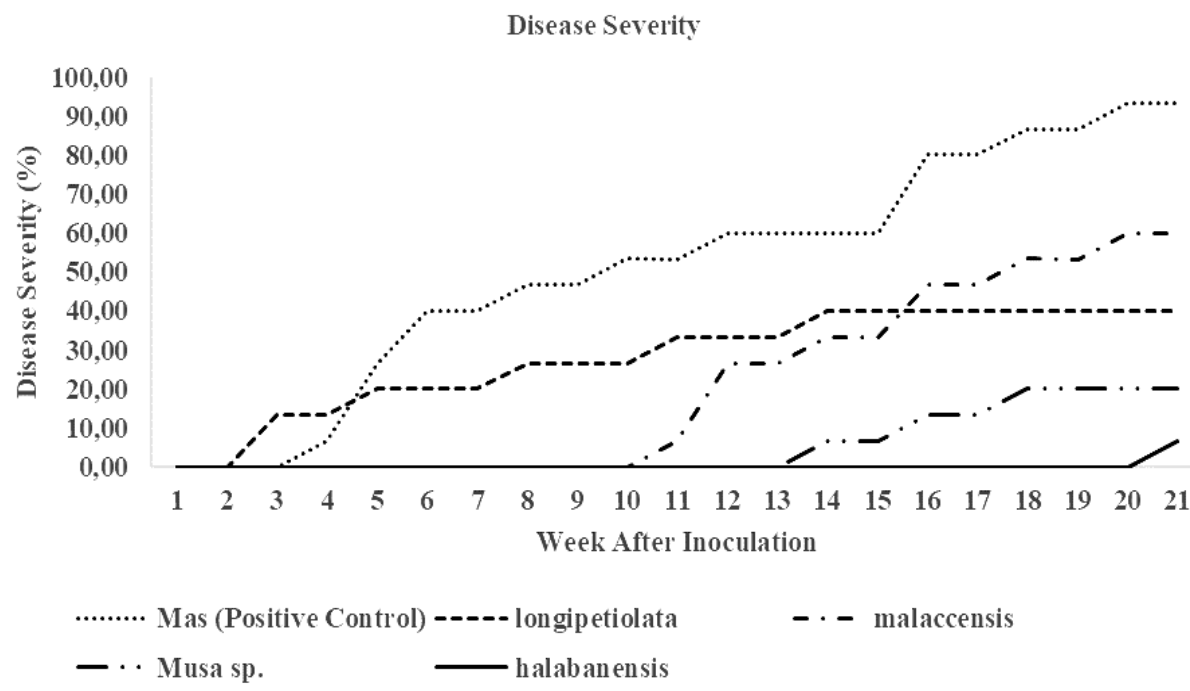

Figure 6. The development of disease severity per week

\section{Discussion}

Edible, cultivated bananas and plantains are descended from wild bananas and a hybrid of wild banana $M$. acuminata Colla (AA) and M. balbisiana Colla (BB). $M$. acuminata has more varieties than $M$. balbisiana. Indonesia is an area of banana origin with a high genetic diversity and known as the center of the species diversity, from the edible, seedless banana (cultivated banana) to the fullseeded banana. The diversity needs to be conserved and preserved in the natural population which is available for banana breeding (Poerba et al. 2019). Wild bananas $M$ acuminata (AA) are widely distributed in Sumatra island. The survey in West Sumatra, Bengkulu, and South Sumatra provinces identified the distribution of some subspecies of M. acuminata i.e. malacensis, longipetiolata, halabanensis, sumatrana, and Musa sp.
The mats primarily spread and grow near rivers and in the rain forests, only a few grow near the villages and the main roads. Most of the habitats have changed to industrial estate crops. Based on the morphological symptoms, two clumps of subspecies sumatrana were found in West Sumatra and Bengkulu provinces. It confirmed a natural infection by BBTV and the putative replication initiation protein (Rep) encoded by DNA-R of the virus amplified at $1104 \mathrm{bp}$ in the subsp. sumatrana. This result indicated the ability of BBTV to infect and replicate their particles in the wild banana. The same genotype between wild Musa and the cultivated banana might affect the successful replication of the virus particles. Furthermore, the survey found that most of the infected bananas belong to the group of AA genotypes (AA, AAA, AAB). 
According to the sequence of DNA-R, BBTV of the wild banana originated from West Sumatra and Bengkulu is in the same cluster with the same virus from the infected Ambon Kuning cultivar from the same locations. It is evident that $P$. nigronervosa has effectively migrated and transmitted the bunchy top virus from cultivated banana to the wild one. The weather might affect the vector survival, migration, and fecundity. Another contributing factor to the effective transmission is the titer of the virus in the aphids (Jebakumar et al. 2018). P. nigronervosa was also able to live in another plant such as Colocasia that grows wild and abundant around the banana mats. Colocasia and other Zingiber families might be the alternative host for BBTV or alternate hosts for $P$. nigronervosa. A previous study indicated the distribution and abundance of $P$. nigronervosa on Musa spp. are genotype-dependent (Ngatat et al. 2017). Recently, the aphid transmitted the BBTV from Ambon Kuning (AAA) to the wild Musa (AA) that grows in the same area. The artificial inoculation has proven that the wild bananas in the $M$ acuminata (AA) group can be infected by BBTV some of them delayed the emergence of the symptoms. The subsp. longipetiolata showed the fastest response to the bunchy top virus infection, however; the disease did not develop well (40\% disease incidence up to 21 weeks after inoculation). This subspecies indicated a resistance response. Subspecies halabanensis delayed emerging symptoms until week $21^{\text {st }}$, longer than other species. Musa sp. showed very good resistant response to the BBTV infection. This species prevents early symptoms for 13 weeks and holds the disease incidence at $20 \%$ until week $21^{\text {st }}$. All species of wild bananas exhibited different resistant responses to BBTV infection. It may be attributed to the unique gene(s) responsible for the resistance of each species that needs to be investigated further.

The more stable DNA components in BBTV are DNA$\mathrm{R}$, DNA-N, and DNA-S. In the recent study, we analyzed DNA-R and DNA-S of the subsp. sumatrana. The putative Rep protein encoded by DNA-R has enzymatic activities including site-specific nicking and join, similar to other Rep proteins. Banana bunchy top virus of the wild banana has two conserved regions, stem-loop common region (CR$\mathrm{SL}$ ) and the major common region (CR-M), both in DNA$\mathrm{R}$ and DNA-S. This corroborates the statement that CR-SL and CR-M are found in all BBTV's component. CR-SL is a conserved region involved in the replication process. This sequence was found in BBTV and other viruses in the Geminivirus group (Wickramaarachchi et al. 2016). This analysis indicated virus capability to replicate after transmission by the vector. When the virus can replicate in the wild banana, the plant could be a new source of the bunchy top disease and an alternative host of the virus.

\section{ACKNOWLEDGEMENTS}

The authors acknowledge The Bill \& Melinda Gates Foundation OPP1130226 for funding this study and the Ministry of Education for the Ph.D. scholarship and the scholarship for International Publication Quality
Improvement (PKPI)/sandwich-like $2018 \quad$ No. 1382.5/D3/PG/2018. This research is a part of research dissertation of the first author.

\section{REFERENCES}

Arumugam C, Kalaimughilan K, Kathithachalam A. 2017. Banana bunchy top viral coat protein $(\mathrm{CP})$ gene expression studies at molecular level in hill banana cv. Sirumalai (AAB). Intl J Curr Microbiol App Sci 6 (6): 398-411. DOI: 10.20546/ijcmas.2017.606.047

Baldodiya GM, Baruah G, Borah BK, Modi MK, Nath PD. 2019. Molecular characterization and sequence analyses of Banana bunchy top virus infecting banana cultivar Jahaji (Dwarf Cavendish) in Assam, India. 3Biotech 9: 110. DOI: 10.1007/s13205-019-1636-5

BPS-Statistic Indonesia. 2019. http//www.bps.go.id.

Chiaki Y, Nasir N, Herwina H, Jumjunidang, Sonoda A, Fukumoto T, Nakamura M, Iwai H. 2015. Genetic structure and diversity of the Banana bunchy top virus population on Sumatra Island, Indonesia. Eur J Plant Pathol 143: 113-122. DOI: 10.1007/s10658-015-0669-9.

Das T, Banerjee A. 2018. Distribution, molecular characterization and diversity of banana bunchy top virus in Tripura, India. Virus Dis 29: 157-166. DOI:10.1007/s13337-018-0451-7.

Debbarma R, Kumar KK, Sudhakar D, Soorianathasundaram K. 2019. Molecular characterization of banana bunchy top virus movement protein-encoding DNA-M component isolated from hill banana and Grand Naine. Electr J Plant Breed 10 (2): 936-943. DOI: 10.5958/0975-928X.2019.00120.0.

Jebakumar RM, Balasubramanian V, Selvarajan R. 2018. Virus titre determines the efficiency of Pentalonia nigronervosa (Aphididae: Hemiptera) to transmit banana bunchy top virus. Virus Dis 29 (4): 499-505. DOI: 10.1007/s13337-018-0493-x.

Ji XL, Yu NT, Qu L, Li BB, Liu ZX. 2019. Banana bunchy top virus (BBTV) nuclear shuttle protein interacts and re-distributes BBTV coat protein in Nicotiana benthamiana. 3 Biotech 9: 121. DOI: 10.1007/s13205-019-1656-1.

Kakathi N, Nath PD. 2018. Genetic diversity of banana bunchy top virus (BBTV) prevalent in Assam causing banana bunchy top disease. Intl J Curr Microbiol Appl Sci 7 (11): 1547-1560. DOI: 10.20546/ijcmas.2018.711.178

Kumar P, Arun V, Lokeswari TS. 2017. Cloning of BBTV (Banana Bunchy Top Virus) components and screening of BBTV using functionalized gold nanoparticles. 3Biotech, 7: 225. DOI: 10.1007/s13205-017-0849-8

Kumar S, Stecher G, Li M, Knyaz C, Tamura K. 2018. MEGA X: Molecular evolutionary genetics analysis across computing platforms. Mol Biol Evol 35 (6): 1547-1549. DOI: 10.1093/molbev/msy096

Lestari SM, Hidayat SH. 2018. Survey and detection of Banana bunchy top virus in Java. IOP Conf Ser Earth Environ Sci 583: 012022. DOI: $10.1088 / 1755-1315 / 583 / 1 / 012022$

Leiwakabessy M, Nurulita S, Hidayat SH. 2017. Disease Incidence and Molecular Analysis of Banana bunchy top virus in Bogor, West Java. In Efendi D, Maharijaya A (eds). The Future of Tropical Horticulture. International Proceeding on Tropical Horticulture 2016: The Future of Tropical Horticulture. Bogor, Indonesia, 28-29 November 2016.

Ngatat S, Hanna R, Kumar PL, Gray SM, Cilia M, Ghogomu RT, Fontem DA. 2017. Relative susceptibility of Musa genotypes to banana bunchy top disease in Cameroon and implication for disease management. Crop Protect 101: 116-122. DOI: 10.1016/j.cropro.2017.07.018.

Poerba Y, Martanti D, Ahmad F. 2019. Genetic variation of wild Musa acuminata Colla. from Indonesia. Biotropia 26 (2): 115-126. DOI: 10.11598/btb.2019.26.2.896.

Qazi J. 2016. Banana bunchy top virus and the bunchy top disease. J Gen Plant Pathol 82: 2-11. DOI 10.1007/s10327-015-0642-7.

Stainton D, Martin DP, Muhire BM, Lolohea S, Halafihi M, Lepoint P, Blomme G, Crew KS, Sharman M, Kraberger S, Dayaram A, Walters M, Collings DA, Mabvakure B, Lemey P, Harkins GW, Thomas JE, Varsani A. 2015. The global distribution of Banana bunchy top virus reveals little evidence for frequent recent, human-mediated longdistance dispersal events. Virus Evol 1 (1): vev009. DOI: $10.1093 / \mathrm{ve} / \mathrm{vev009}$

Suparman, Gunawan B, Pujiastuti Y, Arsi, Cameron RR. 2017. Alternative hosts of banana aphid Pentalonia nigronervosa Coq. 
(Hemiptera: Aphididae), the vector transmitting banana bunchy top virus. J Adv Agric Technol 4 (4): 354-359. DOI: 10.18178/joaat.4.4.

Tchatchambe NBJ, Ibanda N, Adheka G, Onautshu O, Swennen R, Dhed'a D. 2020. Production of banana bunchy top virus (BBTV)-free plantain plants by in vitro culture. Afr J Agric Res 15 (3): 361-366. DOI: $10.5897 / A J A R 2019.14522$

Wickramaarachchi WART, Shankarappa KS, Rangaswamy KT, Maruthi MN, Rajapakse RGAS, Ghosh S. 2016. Molecular characterization of banana bunchy top virus isolated from Sri Lanka and its genetic relationship with other isolates. Virus Dis 27 (2): 154-160. DOI 10.1007/s13337-016-0311-2.

Wirya GNAS, Sudiarta IP, Selangga DGW. 2020. Disease severity and molecular identification of banana bunchy top virus, infecting local banana in Bali Island. Jurnal Perlindungan Tanaman Indonesia 24 (1): 11-16. DOI: $10.22146 /$ jpti.54882. 